\title{
Effect of the Teaching Games for Understanding (TGfU) Method in Improving Students' Motivation And Physical Fitness
}

\author{
Syamsuar *, Zelhendri Zen, Reflianto \\ Sport Education Program \\ Faculty of Sport Science \\ Padang State University \\ Padang, Indonesia \\ syamsuar.unp@fik.unp.ac.id
}

\begin{abstract}
The purpose of this study was to determine the effectiveness of the Teaching Games for Understanding (TGfU) method on fifth-grade students' motivation and physical fitness of elementary school at SDN 11 Sungai Sariak. This research used quantitative research with a quasi-experimental design involving 33 students. The instrument of research used observation sheets, questionnaires, field notes, and interviews. Data analysis used the frequency distribution and inferential analysis with independent $t$-test. Research results revealed that 1) there is a significant difference in students' motivation between TGfU class and conventional class, and 2) there are also significant differences in physical fitness between TGfU class and conventional class. The TGfU method can provide teaching activities with the inductive concept. It leads students to observe and solve the problem during the learning process by stimulating them with many activities. In conclusion, the TGfU method makes students proficient in sport, confident, and able to cooperate with their working group and be able to master all the techniques of the games.
\end{abstract}

Keywords-Effectiveness, Motivation, Physical Fitness, TGfU

\section{INTRODUCTION}

Physical education is taught in schools have an important role to provide opportunities for learners to engage directly in a variety of learning experiences through physical activity, exercise and fitness are selected and systematically performed. "Sport educations has the potential thing to develop their values and social responsibility, a general overview of the social attitudes contained in the method developed is as follows: 1) the level of self-control. This level describes the learner is able to control the behavior, but has not been able to participate actively in all activities. 2) Level of involvement. In this level students have participated in the study from the beginning to the achievement of learning objectives. 3) the level of social responsibility on yourself. In this level, students can learn effectively without having to be directly supervised by the teacher. 4), Level of socially responsible with others. At this level, students are already keen to encourage and help her to learn without having to be told by the teacher to do so" [1].
Danappanavarexplained that physical education is learning to move and learning through movement. It is clear that students are taught to learn the basic movements of the human body, the movement of the feet walking, running, jumping, throwing, catching, creeping, crawling, jumping and other forms of basic movements. Therefore, "sport education has intellectual satisfaction to create excitement a person to cooperate, to work effectively and integrated with all efforts to achieve a good performance in the sport" [2].

To implement of effective learning in physical education, teaching methods that will be used should be required precise and accurate in improving the competence of students' cognitive, affective and psychomotor can be controlled. A development system of teaching methods explained that teacher should be selected in accordance with their ability in teaching materials of sport in the classroom because, learning activities in education, the most urgent and central at the moment is how to formulate the learning method in accordance with the expected competencies. In sports suitability of learning competencies expected is a focus on the student's physical and intellectual

One of interesting teaching in learning the game of small ball in the field is the teaching games for understanding (TGfU). This method is focused how to master in playing the ball in a game. This method is more concerning to tactics and to develop students' physical fitness especially in the elementary school. This method is "expected to increase students' learning motivation and their eager to know how to practice the game truly and can increase their active involvement in following every game they played on the ground" [3].

Output from the application of this method is that students master in the tactics of the game to achieve the feat in a match. Exercise is the key factor in this learning method. The expected outcome of this training process is increasing the students' physical fitness after their attending seriously in the training program of playing the little ball games under their teachers in the field. The advantages of this method is able to improve students' cognitive abilities is not a new concept for the physical education. It can help elementary school teachers in promoting their students' physical fitness to be higher as the effect of the TGfU method implemented. 
Method of TGfUalso can be applied to a child's experience in their school activities to improve the physical fitness and physical health. The election of TGfU method into the game for the sports education to the student were in the elementary school was decided based on the concerning of) to improve performance, b) to accelerate students master in the techniques of the game properly, c) to improve the durability d) to depend on the physical education teacher, e) to enhance the students' understanding and knowledge about the process and flow of a game and the match. "Nonetheless TGFU not balanced in the portion of the activities in which the portion of the activity is more than the portion of selfactualization in sports games" [4].

Meanwhile, the conventional method applied by the sports teacher in teaching small ball game on the students of SDN 11 Sungai Sariak is a method of learning the game. This method is the most common method applied by the sports teacher in teaching physical education at school. The conventional model is more inviting students to play without explaining the technique and mastery of the technique of playing correctlythrough the training process. In learning more are lectures and discussions in teaching about playing techniques. In the implementation of learning the game a little ball as usual, game activities undertaken by teachers in a manner requiring a child to engage in any game is done, without any feedback to the measurement of the achievements of the cognitive, affective and psychomotorchild in detail, especially in measuring students' ability to develop strategies to achieve the feat and measurement of physical fitness of students.

Furtehermore, "the conventional learning by applying the techniques of direct teaching through lecture and discussion.In the learning exercise is more in the direction of, but have not been able to increase students' awareness of the importance of exercise for maintaining physical fitness and the importance of control the movement of sports games correctly to avoid injury during playing the game in the field" [5].

Thus, the method of direct learning with more lectures and discussions in class, but did not provide reinforcement training on the techniques of small ball game properly, techniques such as throwing a ball, catch a ball and technique of move away from ball and other games technique. Therefore, in the students learning activities this method are also involved come into play in the field, but the game is built to run as usual, without any reinforcement the tactics (cognitive), understanding of the rules of the game (affective) and dexterity in the game (psychomotor). From this explanation said that "the conventional method of direct learning technique is more on the involvement of students come and want to play in every match held by teachers in the field" [6].

Based on the description above, a sports teacher in carrying out his duties as an educator is to educate students so that they not only have a high motivation in playing but alsorecognize the nature itself, the potential and talents of the best they have to be trained to become a better player in the future. Through increased student motivation to be high is expected all students to actualize all the potentials themselves with the achievements, can express themselves well in any sport learning, master the technique of the game and the match well and master the theory of playing the small game correctly.

In this way, the application of TGfU methods and conventional methods can basically be developed in order to be able to realize the achievement of quality learning competence, but between these two methods need to know which ones are most effective. It is necessary for measuring the effectiveness between TGFU method and the conventional method using a direct technique lectures and discussions to increase students' motivation and physical fitness.

The comparation of students' effectiveness in the game involvement between TGFU of conventional method. Besides, it is to see which of the two methods are more effective between them especially to increase fifth grade students' learning motivation and physical fitness at SDN 11 Sungai Sariak Padang Pariamanregerency.

\section{RESEARCH METHODOLOGY}

In this research, "the research method was quasiexperimental study by using a comparative research method" [7]. This research emphasis on the comparative effectiveness of fifth grade students' learning motivationand physical fitness in the sports small ball game at SDN 11 Sungai Sariak. The research instrument using a test, questionnaire, interview and documentation. Physical fitness test is performed to measure students' fitness levels. Questionnaires were distributed to students as the respondent to measure their motivation after following both learning methods applied by sports teacher in the classroom. Both of these data are supported by other data such as interviews and field documentation.

This research was conducted at the elementary school in Padang Pariaman Regency namely SDN 11 Sungai Sariak. This research was started from April 2019 to December 2019. The study population was overall fifth grade students in the elementary school at SDN 11 Sungai Sariak totaling 33 people.

Some instruments in this study are as follows:

1. Physical Fitness Test instruments, namely Indonesian Physical Fitness Test (TKJI) is a tool for measuring the quality of ones' physical fitness. This test contains neo motoric test circuit consisting of a few quirks. The whole point is one unit for assessment of physical fitness.

2. Observation is a complex process that is composed of a variety of biological and psychological processes, with their direct observation expected to the findings of further complement naturalistic research. In this study the observation research was conducted at every stage from pre teaching, learning and postteaching learning phase.

3. Questionnaire is a technique of data collection. It is done by giving a set of questions or a written statement to the respondent to answer.In this study, the questionnaire used to measure the response of the 
students' motivation after participating in classroom learning of each methods.

4. Interview is a researcher itself. The researcher interview respondent under guidelines that have been arranged systematically.

5. Documentation, this technique is the process of collecting data by recording the necessary data from sources in the form of reports or monograph in helping to complete the data obtained in the field.

Collecting data by using questionnaires was carried out on a number of considerations including 1) a questionnaire is used to obtain data on the respondents sampled, 2) questionnaire is a data collection tool that is relatively efficient, both in terms of time, cost and effort and the respondent can answer more easily and freely in filling their statement because without being influenced by something that is binding, so the answer is in accordance with what is expected

Quantitative analysis in this study include frequency distribution analysis and inferential statistical analysis. The frequency distribution "is used to analyze the results of the initial survey, which is to see that teachers argue about self-actualization, development thinking of students in school, developing lesson plans, implemention of teaching method, facilities and infrastructure, environment, and students' opinions about the school and the response of students' motivation after following learning methods are given by teachers in the two different classroom with two different treatments.

Inferential statistical analysis used an Independent t-test. This test have function to compare the effectiveness of learning outcomes between TGfU classroom and conventional classroom in the playing of small ball game in terms of students' motivation and their physical fitness. The aim of this study was to see the different effect between different treatment in teaching and learning of small ball game to fifth grade students' motivation and physical fitness, they are TGFU method and conventional method. It was done by calculating the difference of students' motivation achievement and physical fitness test in two classes studied.

Testing of 0.5 percent based on the belief that there is a significant difference between the two methods of learning in the test motivation and physical fitness if the value $\alpha=0.05$, assuming significant value $\alpha>0.05$ then the hypothesis 0 is received, which means there is no significant difference between the two methods were tested, but when the value $\alpha<0.05$ then the hypothesis 0 rejected, which means there is a significant difference between the two methods were tested.

\section{RESULT}

\section{Motivation}

Measurement of fifth grade students' motivation and physical fitnees effect between a conventional class room and TGfU Class room at SDN 11 Sungai Sariak of Padang Pariaman regency can be reported taht this study compiled over 20 questions given through questionnaire to measure fifth grade students' motivation of SDN 11 SungaiSariak. Here are theresults of the analysis of student's answers was agot ten from the motivation quesionaire:

Table 1. Conventional Classroom for Learning Motivation of Students

\begin{tabular}{|l|c|c|c|}
\hline Indicator & Mean & TCR & Expl \\
\hline Interest to learn & 2.3 & 44.5 & Low \\
\hline Sooth & 2.1 & 40.8 & Low \\
\hline Curiosity & 2.2 & 41.6 & Low \\
\hline Practicing spirit & 1.6 & 25.3 & Low \\
\hline Average Score & $2: 05$ & 38.05 & Low \\
\hline
\end{tabular}

Based on data in the first table above shows that the average score for the fifth grade students' motivation in a conventional classroom to follow the sport education in the class of SDN 11 Sungai Sariak about 4.22 with the level of respondents achievement by $33.5 \%$. This shows that the variable of students' learning motivation in the sports to the conventional classroom at SDN 11 Sungai Sariak still low.

From the data found the highest scores was obtained by the indicator of interest and diligent and seriousness highest especially in the question number five is "I'm always excited to be in sports activities in schools" and the question number 8 is' I love to practice although outside hours lesson "with an average score of 2.3 and the level of respondents achievement about $44.5 \%$. Furthermore from here can be seen the Indicators of students' spirit of learning and practice effect to their motivation to be higher. Like in the question number. 15 stated that "I am happy to teach your friends about the correct techniques when practicing" with an average score of 2.2 and the level of respondents achievement about $43.3 \%$. This shows that the spirit of learning and practicing to involve in the playing small game in the filed becomes one of the indicators of all students were in the category of low motivation until enough time to follow the lessons in school sports.

While the lowest average scores obtained in the statement curiosity to question number 14 "I'm trying to find an easy way to master the technique of playing Rondes" with an average score of 1.4 and the level of respondents achievement was generated $22.0 \%$. This shows that the indicators of interest of the students following the sport study in the elementary school No. 11 Sungai SariakPadsangPariamanis still very low.

Overall the research data on students' motivation variable in the conventional classroom at SD Negeri 11 Sungai Sariak by applying the conventional method earned an average score of 2.05 with a level of achievement of $38.05 \%$ of respondents. This shows that the indicators of students' motivation at SDN 11 Sungai Sariak in the conventional classroom is still low.

Measurement of the effect of students' motivation in TGfU classroom at SDN 11 Sungai Sariak also compiled over 20 questions given by using questionaure by using a likert scale in class V of SDN 11 Sungai Sariak. The greater the average scores indicate 
higher motivation that conventional class. Total achievementof students' motivationin TGFU classis as follows:

Table 2 TGfUClassroom for Learning Motivation

\begin{tabular}{|l|c|c|c|}
\hline Indicator & mean & TCR & Ket \\
\hline Interest to learn & 3.5 & 66.1 & High \\
\hline Sooth & 2.9 & 53.3 & Enough \\
\hline Curiosity & 3.2 & 61.8 & High \\
\hline Practicing spirit & 3.3 & 61.2 & High \\
\hline Average Score & 3.2 & 60.8 & High \\
\hline
\end{tabular}

Based on data in Table 2 above shows that the average score of fifth grade students' motivation at SDN 11 Sungai Sariak is about 2.79 with the level of respondents achievement $49.8 \%$. This shows that the variable of students' motivation in SDN 11 Sungai Sariakwere in the category of high.

From the data analysis can be found scores the highest average was obtained by curiosity and enthusiasm indicators for learning and playing the small ball game. It can be revealed from students' answering of the question number 5 is "I'm always excited to be in sports activities in schools" and the question number 8 is' I love to practice although outside of our class"with an average score of 3.5 each and the level of respondent achievement is $66.1 \%$. Further indicators is curiosity and students' motivation is high to TGfU class. It can be seen from the question No. 15 that "I am happy to teach your friends about the correct techniques when practicing" with an average score of 3.3 and the level of achievement of the respondents about $64.2 \%$.

While the lowest average scores obtained on the curiosity indicators like in the question number 14 "I'm trying to find an easy way to master the technique of playing Rondes" with the value of the average score of 2.1 and the level of respondent achievement generated $32.7 \%$. This shows that the indicators of curious looking for an easy trick to master the game Rondes in participating in sports is not optimal learning. In addition to statement No. 17 about eager indicators is to learn and practice is still low, "I follow the practice of sports in the field when the teacher asked the students. It means that the statement showed the students' motivation in the class while following subjects rounders game in TGfU class will be high when supervised by their teachers.

Overall the research data on students' learning motivation following the education sports of playing the small ball game in SDN 11 Sungai Sariak obtained an average score of 3.2 with the level of respondent achievement of $60.8 \%$. It shows that the indicators of students' learning motivation to the sport education at SDN 11 Sungai Sariakwasstill in the High category.

Having ascertained through normality test data that the second data has been declared normal, and then the action of t-test to determine the difference of students' learning motivation between TGFU classroom and conventional classroom.Based on statistical analysis of independent-test the result can be shown in Table 3 below.
Table 3. Hypothesis Testing with Independent t-test for Students' Motivation Effect

\begin{tabular}{|l|c|c|c|c|}
\hline \multicolumn{1}{|c|}{ Data } & $\begin{array}{c}\mathrm{t}- \\
\text { count }\end{array}$ & Sig & df & Information \\
\hline $\begin{array}{l}\text { Experimenvs } \\
\text { Control }\end{array}$ & 3,703 & 0000 & 52 & $\begin{array}{c}0.000<0.05 \\
\text { Significant }\end{array}$ \\
\hline
\end{tabular}

By using SPSS version of 17 can be obtained the output of this analysis determined the significance level of $0.000<0.05$, it means that there are significant differences of s'udents' learning motivation between TgfU classroom and conventional classroom. In the TGfU classroom is applied by teacher determined that the students' learning motivation to be improved higher than conventional classroom did at SDN 11 Sungai Sariak. It proved that TGfU is able to give the motivational effect is higher than in a conventional classroom.

\section{Physical Fitness}

Through computer calculations by using SPSS version 17.0 it is known that the average score (mean) 10.61 ; mode of 8.00; the middle score (median) of 11.00; and a standard deviation of 2.091. The frequency distribution class scores can be seen in Table 4 below.

Table 4. Frequency of physical fitnessof students in the conventional class

\begin{tabular}{|c|c|c|}
\hline \multirow{4}{*}{$\mathrm{N}$} & & Methods TGFU \\
\hline & Valid & 33 \\
\hline \multirow{7}{*}{} & Missing & 0 \\
\cline { 2 - 3 } & Mean & 10.61 \\
\cline { 2 - 3 } & Median & $11: 00$ \\
\cline { 2 - 3 } & Mode & 8 \\
\cline { 2 - 3 } & Std. deviation & 2,091 \\
\cline { 2 - 3 } & Minimum & 7 \\
\cline { 2 - 3 } & maximum & 14 \\
\cline { 2 - 3 } & Sum & 350 \\
\hline
\end{tabular}

Based on statistical data obtained can be presented the categories of acquisition tendency of physical fitness score of students in a conventional classroom at SDN 11 Sungai Sariak were in the range 714 value with an average value of 10.61 . This point was in the low category.

Through computer calculations by using SPSS version 17.0 it is known that the average score (mean) of 13.27; mode of 12.00; the middle score (median) of 13.00; and a standard deviation of 2.897. The frequency distribution scores of TGfU class can be seen in Table 5 below. 
Table 5. Frequency of Physical Fitnessof students In TGfU Class room

\begin{tabular}{|c|c|c|}
\hline \multirow{4}{*}{$\mathrm{N}$} & Valid & $\begin{array}{c}\text { methods of } \\
\text { Inquiry }\end{array}$ \\
\hline \multirow{4}{*}{} & Missing & 33 \\
\hline & Mean & 0 \\
\cline { 2 - 3 } & Median & $16: 27$ \\
\cline { 2 - 3 } & Mode & $16: 00$ \\
\cline { 2 - 3 } & Std. deviation & 2,897 \\
\cline { 2 - 3 } & Minimum & 8 \\
\cline { 2 - 3 } & Maximum & 20 \\
\cline { 2 - 3 } & Sum & 438 \\
\hline
\end{tabular}

Based on statistical data obtained can be presented the tendency of acquisition categories of physical fitness score of students in a conventional classroom at SDN 11 Sungai Sariak were in the range 820 value with the average value of 16.27 . it was in the high category.

Theeffectiveness of students' physical fitness between the control group and the experimental group at SDN 11 Sungai Sariak can be seen from the result of independent t-test. This test can determine the differences of students' physical fitness achievement among the group studied both learning was taught by TGfUmethod (experimental class) and conventional with lecture and discussion method (control class). There is a significant difference between the two groups of result of students' performance score in the test results of their physical fitness that can be seen in table 6 below.

Table 6. Hypothesis Testing with Independent t-testfor Students' Physical Fitness Effect

\begin{tabular}{|c|c|c|c|c|}
\hline Data & t-count & Sig & df & Information \\
\hline $\begin{array}{l}\text { Experiment } \\
\text { vs. Control }\end{array}$ & 6288 & 0017 & 64 & $\begin{array}{c}0.017<0.05 \\
\text { Significant }\end{array}$ \\
\hline
\end{tabular}

From the table above it can be seen the result of $\mathrm{t}$-count was 6.288 with df 64 . The consultation with $\mathrm{t}$ table value at $5 \%$ as significance level and. Scores t-table at a significance level of $5 \%$ with df64 is 0.017 . It showed significantly smaller value than $0.005(0.017<0.05)$. Thus the test results of independent t-test between the experimental class and the control class showed a significant difference, namely an increase in the final score of students' physical fitness test is higher when teacher used the TGfU Treatment. In other words TGfU method is more effective in increasing students's physical fitness than conventional method.

\section{DISCUSSION}

Based on hypothesis testing fifth grade students' motivation at elementary school in learning the game of small ball at SDN 11 can be discussed that the hypothesis results of fifth grade students' motivation between the two class were studied with two different learning method those are TGfU and conventional with lecture and discussion method. From the result of this research showed that there are significant differences of students' learning motivation to each method applied by sport teacher in the class, TGFU classroom and conventional classroom. The results of the analysis proved the hypothesis that TGfU more is effective than conventional class in increasing motivation and learning outcomes of fifth grade students' motivation at SDN 11 Sungai Sariak Padang Pariaman. The results of this study revealed that by the increase motivation score of each tested method is proven TGfUis linearity in giving positive effect to students' motivation where by this method learner can increase their motivation to involve actively in all sport exercises and the game as can be seen in the table below:

Table 7. Comparison of Students's Motivation of Each Class

\begin{tabular}{|l|c|c|l|}
\hline \multirow{2}{*}{ Class } & \multicolumn{2}{|c|}{ Motivation } & \multirow{2}{*}{ Category } \\
\cline { 2 - 3 } & $\begin{array}{c}\text { Average } \\
\text { Score }\end{array}$ & TCR & \\
\hline TGfU Class & 1.86 & 33.5 & Low \\
\hline $\begin{array}{l}\text { Conventional } \\
\text { Class }\end{array}$ & 2.79 & 49.8 & Enough \\
\hline
\end{tabular}

From table above shows there is a significant difference of students 'motivation in participating to the sport exercises particularly in playing the small ball game than the conventional methods applied by discussion in the fileld. From the result can be resumed that TGfU can improve fifth grade students' learning motivation at SDN 11 Sungai Sariak Padang Pariaman with a students' performance value of $60.6 \%$, higher than the conventional class which jus has a score of $38.05 \%$.

From the results of the hypothesis shows that the t-test between TGfUclassroom and conventional classroom by using SPSS 17.0 generate a significantdifferent in achievement of student's learning motivation, which is $0.000<0.05$, It means that there are significant differences between TGfU method and conventional methods in improving students' motivation, which TGFU method is much better to increase students' motivation compared to conventional methods.

Meanwhile, comparison of students' physical fitness results between TGfUclassroom and conventional classroom where TgfU method is better in improving students' physical fitness than conventional classroom as shown in the following table:

Table 8. Comparison of Students's Physical Fitness of Each Class

\begin{tabular}{|l|c|c|l|}
\hline \multirow{2}{*}{ Class } & \multicolumn{2}{|c|}{ Score } & \multirow{2}{*}{ Category } \\
\cline { 2 - 4 } & $\begin{array}{c}\text { Average } \\
\text { score }\end{array}$ & SD & Well \\
\hline TGfU Class & 16,27 & 2,897 & Less \\
\hline $\begin{array}{l}\text { Conventional } \\
\text { Class }\end{array}$ & 10.61 & 2,091 & \\
\hline
\end{tabular}


Of the two analysisabove, it is concluded that there are differences effect in results for the students' achievement in getting physical fitness between TGfU method and conventional, wherein the TGfUmethod is better in the achievement of student learning outcomes of physical fitness with the average value of 16.27 is higher than the achievements of students' physical fitness in the conventional class just 10.61 .

After a comparison test was conducted by using independent t-test showed that there is a significant difference between conventional classroom methods and TGFU method in giving effect to students' learning motivation premises with significant values $\alpha=0.000$ $<0.005$, it can be concluded that TGfUmethod is more effective than conventional classroomin increasing students' motivation and physical fitness at SDN 11 Sungai Sariakof PadangPariamanRegerency.

\section{CONCLUSION}

From the results of research and discussion above it can be concluded that there are significant differences between classroom learning motivation between TGfUmethod and conventional with lecture and discussion method. TGfU method is more effective in improving students' motivation and physical fitness at SDN 11 Sungai Sariak of Padang Pariamanregency. For sport teachers at elementary school is suggested to use TGfU method in learning student to exercise the game of small ball such rounder and other related games.

\section{REFERENCES}

[1] D. R. Hellison, "Teaching personal and social responsibility through physical activity". Human Kinetics, 2010. pp. 12-13

[2] K. G. G. Danappanavar, "Study of occupational stress between male and female physical education teachers of government senior secondary schools of Vijayapur," 2019. pp. 25-26

[3] J. V. S. Ríos, E. Guijarro, I. Rocamora, and J. L. C. Marinho, "Teaching Games for Understandings vs Direct Instruction: levels of physical activity on football U-12," Educ. Sport. Heal. Phys. Act. Int. J., vol. 3, no. 1, pp. 46-55, January. 2019.

[4] S. Nathan, "Commentary: Teaching Games of Understanding (TGfU) coaching effects on Heart Rate among Malaysian and Indian Junior Hockey Players," J Cardiol Cardiovasc Sci. J Cardiol
Cardiovasc Sci., vol. 3, no. 3, pp. 14-20, march, 2019.

[5] D. Budiana, D. Budiman, and T. I. W. Budiman, "Pendidikan Olahraga", Jurnal Pendidikan Jasmani dan Olahraga, vol. 2, no. 2, pp 28-23, Oct. 2019.

[6] G. A. Toto and P. Limone, "Self-directed learning: An innovative strategy for sport and physical education," 2019. pp. 34-35

[7] J. Creswell W. "Research Design, Qualitative, Quantitative and Mixed Methods Approaches". 4th ed. SAGE Publication, Inc, 2014. pp. $45-52$ 